\title{
BEATA LEWIŃSKA*
}

Wydział Nauk Historycznych i Społecznych

Uniwersytet Kardynała Stefana Wyszyńskiego, Warszawa

\section{STANISŁAW SHEYBAL I JEGO ROLA W KRZEWIENIU KULTURY PLASTYCZNEJ I EDUKACJI ARTYSTYCZNEJ W POLSCE}

\section{Wstęp}

Postać Stanisława Sheybala (I89I-I976), malarza, znakomitego fotografika, współorganizatora wielu przedsięwzięć o charakterze kulturalnym i artystycznym, metodyka, organizatora życia artystycznego (w tym różnych form konfrontacji), a także szkoleń dla nauczycieli muzyki, plastyki oraz - po II wojnie - nauczycieli przedmiotów artystycznych szkolnictwa artystycznego była przedmiotem wielu badań, prowadzonych przede wszystkim przez prawnuczkę artysty - Aleksandrę Sheybal-Rostek ${ }^{1}$. Publikacje tej autorki ukazywały się w latach 2008-20II. Losy rodziny opisała przede wszystkim w artykule: W cieniu Góry Bony - rzecz o rodzinie Sheybalów, wydanej w „Pamiętniku Kijowskim”. Jej artykuł, dotyczący fotograficznej działalności Sheybala, Stanisław Sheybal (I89I-I976), krzemieniecki nauczyciel, działacz kulturalny, malarz i fotograł , przede wszystkim podejmuje wątek działalności Sheybala na polu fotografii - zwłaszcza w okresie, kiedy był on pracownikiem legendarnego Liceum Krzemienieckiego. Z kolei: Stanisław Sheybal-krzemieniecki „,mecenas” sztuki ${ }^{4}$ to artykuł poświęcony opisowi prowadzonych w Krzemieńcu plenerów malarskich dla plastyków. Pisała także o tych plenerach Teresa Skórzewska5. We współpracy Aleksandry Sheybal-Rostek i Dariusza Szlawskiego powstał artykuł Stanisław Sheybal (I89I-1976). Szkic do portretu, opublikowany w „Roczniku Miasta Zgierza”, w którym Sheybal mieszkał i pra-

* Beata Lewińska - doktor, pracownik Instytutu Historii Sztuki UKSW. Absolwentka historii sztuki na KUL, studiów doktoranckich w Instytucie Sztuki PAN, podyplomowych studiów pedagogicznych w Instytucie Badań Edukacyjnych MEN i zarządzania oświatą na Uniwersytecie Warszawskim. Zainteresowania badawcze - dydaktyka sztuki, artyści dydaktycy, polski pejzaż 1 połowy XX wieku. Autorka książki: Kształcenie artystyczne w szkołach plastycznych w Polsce w latach 1944-2017, Wydawnictwo Naukowe UKSW, Warszawa 2018.

1 Aleksandra Sheybal-Rostek, przedstawiająca się jako „miłośniczka Warszawy”, jest wnuczką Kazimierza Sheybala, syna Stanisława.

2 A. Sheybal-Rostek, W cieniu Góry Bony - rzecz o rodzinie Sheybalów, „Pamiętnik Kijowski”, 2008, t. 9, s. 269282.

3 Eadem, Stanisław Sheybal (1891-1976), krzemieniecki nauczyciel, działacz kulturalny, malarz i fotograf, „Dagerotyp", 2010, nr 19, s. 63-71, na stronach 60-63 prezentowane są dodatkowo fotografie z życia artysty.

4 Eadem, Stanisław Sheybal - krzemieniecki „, mecenas” sztuki w: Plenery krzemienieckie w latach trzydziestych XX wieku, red. J. Grabski, W. Drohobycka-Grzesiuk, IRSA, Kraków 2013, s. 171-183.

5 T. Skórzewska, Wakacyjne Kursy Rysunkowe w Krzemieńcu, „Arkady”, 3/1937, nr 10, s. 547. 
cował przez 8 lat ${ }^{6}$. We wszystkich wymienionych artykułach, Aleksandra Sheybal-Rostek omówiła dosyć wnikliwie techniki fotograficzne, którymi posługiwał się Stanisław Sheybal oraz jego dokonania w tym zakresie. Odwoływała się też do jego twórczości malarskiej. Autorka powyższych publikacji prowadzi też stronę internetową, na której w zakładce $O$ mnie zamieściła liczne fotografie członków swojej rodziny i przedstawiła ich losy7, a w zakładce Krzemieniec przypomina sławę tego niezwykłego miasta i jego rolę na polu kultury w czasach funkcjonowania słynnego Liceum Krzemienieckiego ${ }^{8}$. Wiele informacji pochodzi też z publikacji własnych Stanisława Sheybala, takich jak Wspomnienia I89I-I9709 czy artykuł Ruch fotograficzny w Krzemieńcu, opublikowany w „Życiu Krzemienieckim”. Życiorys artysty został ustalony i opublikowany Polskim Stowniku Biograficznym ${ }^{\text {II }}$. Przez Aleksandrę Sheybal-Rostek został uzupełniony o niektóre fakty z życia artysty, ustalone na podstawie dokumentów zachowanych rodzinie i pozostawionego przez artystę życiorysu.

Można powiedzieć, że o Stanisławie Sheybalu napisano już wiele. Warto jednak pokazać sylwetkę artysty w szerszym kontekście, aby podkreślić rolę, jaką pełnił w rozwoju kultury artystycznej (plastycznej i muzycznej), szkolnictwa artystycznego. Zwłaszcza, że okres po II wojnie światowej w powyższych publikacjach, z wyjątkiem materiału źródłowego, jakim są Wspomnienia I89I-I970 - prawie nie został podjęty.

\section{Stanisław Sheybal i pierwsze kontakty z dydaktyką}

Stanisław Sheybal pracą pedagogiczną zainteresowany był już od czasów studiów. Będąc od I9II roku studentem krakowskiej Akademii Sztuk Pięknych ${ }^{12}$ (najpierw przez rok jako wolny słuchacz, a potem student zwyczajny w pracowni Teodora Axentowicza), równocześnie uczęszczał na wykłady z matematyki i przedmiotów pedagogicznych na Uniwersytecie Jagiellońskim ${ }^{13}$. Pracował wówczas w zakładzie fotograficznym swojego stryja Józefa, gdzie uczył się rzemiosła fotograficznego. Poznał tam procesy fotograficzne i zasady powstawania obrazu. Już wtedy pragnął być nauczycielem, a kandydatom na nauczycieli rysunków w szkołach średnich stawiano wymagania, aby jednocześnie zdobyli kwalifikacje do nauczania matematyki w klasach niższych szkoły średniej, jako drugiego przedmiotu. Z tego powodu Ministerstwo Wyznań Religijnych i Oświecenia Publicznego wymagało co najmniej dwóch lat studiów uniwersyteckich ${ }^{14}$. Podczas studiów, wraz z wujem, chodził na koncerty i wystawy. Wiedzę teoretyczną na temat historii sztuki zdobywał na wykładach Lucjana Rydla w ASP. Tak pisał o nich: „W wykładach swoich mniej dbał o rzeczowe podawanie faktów i o chronologiczną ciągłość dziejów sztuki. [...] On nas wychowywał. Budził ogólne

\footnotetext{
6 A. Sheybal-Rostek, D. Szlawski, Stanisław Sheybal (1891-1976). Szkic do portretu, ,Zgierskie Zeszyty Regionalne", 2012, t. 7, s. 113-128.

7 Eadem, O mnie, http://sheybal.pl/kategoria/o-mnie/ (dostęp: 11.11.2018).

8 Eadem, Krzemieniec, http://sheybal.pl/kategoria/krzemieniec/ (dostęp: 11.11.2018).

9 S. Sheybal, Wspomnienia 1891-1970, Wydawnictwo Literackie, Kraków 1984.

10 Idem, Ruch fotograficzny w Krzemieńcu, ,Życie Krzemienieckie”, 1932, nr 8-9, s. 8.

11 A. Patek, Sheybal Stanisław Józef, w: Polski Stownik Biograficzny, t. 36, Warszawa-Kraków 1995, s. $435-437$.

12 A. Sheybal-Rostek, Stanisław Sheybal (1891-1976), krzemieniecki nauczyciel, działacz kulturalny, malarz i fotograf, op. cit., s. 64.

13 S. Sheybal, Wspomnienia ..., op. cit., s. 114.

14 Ibidem, s. 136.
} 
zainteresowanie twórczością artystyczną, zawsze na tle warunków epoki i środowiska, rozwijał wrażliwość na jej nieprzemijające wartości oraz entuzjastyczną miłość do sztuki i potrzebę ciągłego z nią obcowania"'I5. Już wtedy Sheybal dochodził do swoistych refleksji na temat metod dydaktycznych,

Po odzyskaniu niepodległości Stanisław Sheybal zamieszkał w Krakowie, skąd przeniósł się do Zgierza. Aby utrzymać rodzinę w I9I9 roku podjął pracę nauczyciela rysunku w Państwowym Gimnazjum w Zgierzu. Było to jego pierwsze zetknięcie z pracą nauczycielską i pierwsze z nią związane doświadczenia. Skupił się wówczas na dydaktyce. Jak pisał: „,Szkoła ta była wręcz wymarzonym terenem pracy pedagogicznej i osiem lat trwająca w niej praca pozwoliła mi wniknąć w sens różnorodnych zagadnień dydaktyczno-wychowawczych, poznać różne metody pedagogicznej działalności oraz przeprowadzić drogą doświadczalną ich badania i selekcję ich praktycznej wartości”’6. Oprócz pracy w gimnazjum angażował się w inne przedsięwzięcia. Współpracując ściśle ze Związkiem Nauczycielstwa Polskiego w Zgierzu, był inicjatorem powstania Uniwersytetu Robotniczego, na którym prowadził pogadanki na temat sztuki i muzyki. Prowadził je erudycyjnie, ilustrując bogato reprodukcjami dzieł sztuki i granymi na żywo, a nawet śpiewanymi utworami muzycznymi.

Artysta wychowywał się w domu, gdzie panowała wysoka kultura muzyczna, a sam grał na fortepianie i skrzypcach ${ }^{17}$. Prowadził też w swoim życiu amatorskie zespoły muzyczne ${ }^{\mathrm{r} 8}$. Miał zatem rozległą wiedzę zarówno o sztukach plastycznych jak i muzyce.

Podczas pobytu w Zgierzu powołano artystę na kierownika kursu przedmiotów ogólnokształcących i zawodowych dla terminatorów i czeladników rzemiosła. Ukończenie kursów było wówczas warunkiem przystąpienia do egzaminu mistrzowskiego. Zatem zdobywał doświadczenia pedagogiczne zarówno w pracy z dziećmi jak i dorosłymi.

\section{Czas Krzemieńca}

W 1937 roku, z inicjatywy Franciszka Hilczera, Sheybal dostał propozycję pracy w Liceum Krzemienieckim, zwanym Atenami Wołyńskimi. Osławione i powszechnie znane Liceum Krzemienieckie, założone w I805 roku przez Tadeusza Czackiego i zamknięte w I832 roku, doczekało się szeregu opracowań ${ }^{19}$. W 1920 roku, rozkazem nr I62 Naczelnego Wodza z dnia 27 maja I920 r. o otwarciu i rozkazem nr I63 o majątkach Liceum Krzemienieckiego ${ }^{20}$, zostało reaktywowane po „Cudzie nad Wisłą” i stało się w II Rzeczypospolitej przedmiotem szczególnej troski rządu polskiego. Rozporządzeniem z dnia Io sierpnia 1922 zostały uregulowane zasady organizacyjne. Na czele liceum władzę sprawował wizytator, który podlegał bezpośrednio Ministrowi Wyznań Religijnych i Oświecenia Publicznego i posiadał w stosunku do zakładów naukowych, wychowawczych i oświatowych zespolonych w li-

\footnotetext{
15 Ibidem, s. 122.

16 Ibidem, s. 217.

17 Ibidem, s. 36.

18 Ibidem, s. 227.

19 R. Przybylski, Krzemieniec. Opowieść o rozsądku zwyciężonych, Wydawnictwo Sic, Warszawa 2003; M. Rolle, Ateny Wołyńskie. Szkic z dziejów oświaty w Polsce, Ossolineum, Wrocław 1923; J. Skłodowski, Krzemieniec Aten Wolyńskie - Wolyn Athens, Ad Oculos, Warszawa 2006; A. Sheybal-Rostek, Krzemieniec i Liceum Krzemienieckie, „Niepodległość i pamięć”, 2008, nr 27, s. 305-329.

20 Publikowane w Dziennikach Urzędowych Zarządu Cywilnego Ziem Wołynia i Frontu Podolskiego z 1920 r., nr 12 , poz. 162 .
} 
ceum oraz ich personelu administracyjnego i nauczycielskiego prawa i obowiązki kuratora okręgu szkolnego. Rozporządzenie ustalało też zasady powoływania Rady Pedagogicznej w przedmiocie Liceum Krzemienieckiego ${ }^{21}$. Kolejnym rozporządzeniem z dnia 3 czerwca I927 roku ustalono zasady organizacyjne i zasady finansowania Liceum Krzemienieckiego ${ }^{22}$.

Franciszek Hilczer, wykładowca Liceum Krzemienieckiego, zainteresował osobą Sheybala Juliusza Poniatowskiego. Ten ekonomista, kilkakrotny minister rolnictwa, poseł i wicemarszałek sejmu I kadencji, w latach $1927-34$ był kuratorem Liceum Krzemienieckiego ${ }^{23}$. Do placówki szukał w tym czasie nowych nauczycieli.

W roku 1927, kiedy podjął pracę Sheybal, Liceum Krzemienieckie było placówką edukacyjną, na którą składało się kilkanaście szkół i ośrodków szkoleniowych ${ }^{24}$. Sheybal został mianowany tymczasowym nauczycielem Państwowego Seminarium Nauczycielskiego w Krzemieńcu ${ }^{25}$. Jako nauczyciel rysunku wiedział, że powinno się zreformować sposób nauczania tego przedmiotu w szkołach powszechnych. „Warunki panujące w Liceum Krzemienieckim, a także niebywałe piękno okolicy Krzemieńca i specyficzny charakter tego zabytkowego miasteczka, położonego wśród wzgórz i lasów, sprzyjały również rozwijaniu i poszerzaniu zakresu działania nauczyciela plastyki, który w innych szkołach, zgodnie z obowiązującym wówczas (i jeszcze znacznie później) programem «rysunku» uczył przede wszystkim umiejętności obiektywnego odrysowania przedmiotu. Tak ciasno pojęty cel nauczania nie wyczerpał w moim przekonaniu sprawy. Już wtedy wiedziałem, że szkoła winna m.in. przez sztukę dążyć do formowania osobowości ucznia. Obok rysunku, malarstwa, grafiki, formowania przestrzennego, wiadomości o sztuce itp., niepoślednie, moim zdaniem, miejsce zająć powinna również fotografia, której uprawianie daje uczniom pełną możliwość wyżycia się twórczego"26. Jak zatem wynika z przytoczonej wypowiedzi, Sheybal przedkładał swobodną ekspresję twórczą dziecka nad uczenie mimetycznego odtwarzania przedmiotów.

Sheybal zdawał sobie sprawę, że fotografia daje możliwości interpretacji natury. Uczy też zasad komponowania obrazu i dostosowania ich do wizji artystycznej w celu uzyskania właściwych efektów. Uważał nawet, że dobrze prowadzona fotografia może być także środkiem rozwijania wyobraźni i myślenia plastycznego, a nawet pełnowartościowym środkiem wychowania estetycznego ${ }^{27}$. O wychowaniu estetycznym nie zapomniał także w czasach późniejszych.

Wraz z zatrudnieniem Sheybala w Liceum Krzemienieckim powierzono mu zorganizowanie i poprowadzenie pracowni fotograficznej. Pracownia, którą stworzył w I928 roku, miała charakter międzyszkolny. Równocześnie artysta intensywnie pogłębiał swoją wiedzę na temat tej coraz prężniej rozwijającej się dyscypliny. Uczestnicy jego zajęć fotografowali przede wszystkim architekturę Krzemieńca i jego plenery. W organizowaniu wystaw i konkursów Sheybal współpracował z jednym z najwybitniejszych wówczas fotografów polskich - Janem

\footnotetext{
21 Rozporzadzenie Rady Ministrów z dnia 10 sierpnia 1922 r. w przedmiocie Liceum Krzemienieckiego, Dziennik Urzędowy Rządu Polskiego z 1922 r., nr 70, poz. 626.

22 Rozporzadzenie Rady Ministrów z dnia 3 czerwca 1927 roku o zmianie rozporządzenia Rady Ministrów z dnia 10 sierpnia 1922 r. w przedmiocie Liceum Krzemienieckiego, Dziennik Ustaw z 1927 r., nr 63, poz. 556.

23 A. Bieńkowska, Juliusz Poniatowski. Biografia polityczna, Wydawnictwo Neriton, Warszawa 2012.

24 S. Sheybal, Wspomnienia ..., op. cit., s. 240.

25 A. Sheybal-Rostek, Stanisław Sheybal (1891-1976)..., op. cit., s. 173.

26 S. Sheybal, Wspomnienia..., op. cit., s. 240.

27 Ibidem, s. 241.
} 
Bułhakiem $^{28}$. Sam eksperymentował przede wszystkim z wykorzystaniem tak zwanej techniki gumy. Jest to to technika, w której materiałem światłoczułym jest guma arabska, zawierająca odpowiedni barwnik, uczulona dwuchromianem potasowym na działanie światła. Warstwę gumy arabskiej naświetla się poprzez negatyw fotograficzny, a następnie płucze wodą. Miejsca znajdujące się pod przezroczystymi miejscami negatywu stają się odporne na wodę, natomiast miejsca nie naświetlone stają się rozpuszczalne w wodzie. Technika ta daje duże możliwości interpretacyjne i kreacyjne i zaliczana jest do szlachetnych technik fotografii ${ }^{29}$.

Grono uczniów korzystających z pracowni fotograficznej Liceum Krzemienieckiego stale się powiększało. Tak pisał Sheybal w pamiętniku: ,praca z nimi, śledzenie ich postępów oraz często zaskakujących oryginalnością i poziomem inwencji twórczych w dziedzinie tematu, formy, treści i wyrazu emocjonalnego dawało wiele zadowolenia i radości"3o. Dodatkowo utworzył i kierował szkolną pracownią radiotechniczną. O tym okresie życia artysty tak pisała jego prawnuczka: „Czas pobytu w Krzemieńcu był dla Sheybala okresem najintensywniejszej pracy. Przede wszystkim absorbowała go zawodowa praca nauczyciela wychowania plastycznego, a w późniejszych latach również metodyka nauczania rysunków, wiedzy o sztuce i geometrii wykreślnej" ’3. Sheybal angażował się czynnie w życie artystyczne Krzemieńca, był współtwórcą wielu wystaw, inicjatorem i redaktorem „Życia Krzemienieckiego", czasopisma które ukazywało się w latach I932-I939.

Jedną z najważniejszych prac Sheybala było zorganizowanie w Krzemieńcu Muzycznych Ognisk Wakacyjnych - spotkań dla nauczycieli, które zorganizowano przy pomocy Wydziału Kształcenia Nauczycieli Ministerstwa Wyznań Religijnych i Oświecenia Publicznego ${ }^{32}$. W paragrafie I Komunikatu Ministerstwa Wyznań Religijnych i Oświecenia Publicznego w sprawie Statutu Muzycznego Ogniska Wakacyjnego dla nauczycielstwa szkół ogólnokształcących i seminarium nauczycielskich w Krzemieńcu (który zaczął obowiązywać od I5 czerwca I929 roku) zapisano: „Ognisko wakacyjne ma na celu pogłębienie i rozszerzenie kultury muzycznej w kraju przez a) przygotowanie uzdolnionych nauczycieli śpiewu i muzyki, kierowników chóru, dyrygentów orkiestr amatorskich i zespołów amatorskich; b) organizowania konkursów, koncertów i odczytów muzycznych; c) prowadzenie poradni muzycznej" 33 .

Zgodnie z tym statutem, prowadzenie ogniska powierzone zostało Liceum Krzemienieckiemu. Do ogniska przyjmowano zgłoszenia nauczycieli muzyki wszystkich szkół powszechnych, publicznych i prywatnych oraz szkół innego typu, a nawet dyrygentów orkiestr amatorskich niebędących nauczycielami. Pierwszeństwo przysługiwało nauczycielom z okręgu wołyńskiego. Kandydaci na kurs Muzycznego Ogniska Wakacyjnego musieli zdać egzamin z muzyki (jeśli nie mieli udokumentowanego ukończenia studiów muzycznych). W ognisku tym prowadzone były różnorodne kursy, które trwały od Io dni do 6 tygodni. Były to kursy śpiewu w zakresie programu Wyższego Kursu Nauczycielskiego, muzyki

28 Ibidem, s. 242.

29 Słownik terminologiczny sztuk pięknych, Wydawnictwo Naukowe PWN, Warszawa 2003, s. 143.

30 Ibidem, s. 244.

31 A. Sheybal-Rostek, Stanisław Sheybal-krzemieniecki ,mecenas” sztuki, op. cit., s. 177.

32 Ibidem, s.177.

33 Komunikat Ministerstwa Wyznań Religijnych i Oświecenia Publicznego w sprawie Statutu Muzycznego Ogniska Wakacyjnego dla nauczycielstwa szkół ogólnokształcacych i seminarium nauczycielskich w Krzemieńcu, Dziennik Urzędowy Ministerstwa Wyznań religijnych i Oświecenia Publicznego z 1929 r., nr 7, poz. 110. 
i śpiewu dla nauczycieli szkół średnich, kursy gry na instrumencie, kursy z zakresu prowadzenia orkiestr i zespołów. Zgodnie ze statutem, obowiązkiem liceum było też prowadzenie poradnictwa dla nauczycieli, którzy byli uczestnikami kursów podczas ich pedagogicznej pracy w ciągu roku szkolnego ${ }^{34}$.

Sukces MOW przyczynił się do zorganizowania i prowadzenia wakacyjnych kursów fotografii i malarstwa dla nauczycieli plastyki, które rozpoczęły się osiem lat później, w I938 roku, a których jednym z wykładowców i inicjatorów był Stanisław Sheybal. Na wzór kursu muzycznego nazwano ten kurs Rysunkowym Ogniskiem Wakacyjnym. Jak podaje Teresa Skórzewska ${ }^{35} \mathrm{~W}$ artykule poświęconym ROW dla nauczycieli, wybitny polski malarz kolorysta, Emil Krcha, który wówczas mieszkał w Krzemieńcu, podsunął Sheybalowi myśl, aby ogniskami tymi zainteresował Kazimierza Miterę, malarza, pedagoga i krytyka sztuki, którego pasją było szerzenie kultury plastycznej i zamiłowania do malarstwa. Tak się złożyło, że ogniska zostały zainicjowane w roku śmierci Mitery, a ich kierownikiem został Władysław Lam, kolega Sheybala z krakowskiej ASP ${ }^{36}$.

W ROW pracowali tacy twórcy, jak: Jan Cybis, Hanna Rudzka-Cybisowa, Emil Krcha, Eustachy Wasilkowski, Leon Ormezowski, Czesław Rzepiński, Kazimierz Rutkowski, Stanisław Szczepański, Jerzy Wolff oraz rzeźbiarz Marian Wnuk ${ }^{37}$. Sheybal w swych wspomnieniach dodaje jeszcze, że także Hanna Rudzka-Cybisowa, Adam Gerżabek i Kazimierz Tomorowicz. Znakomita plejada artystów polskich, głównie kolorystów, postawiła sobie za cel krzewienie kultury plastycznej. Jak podaje Tchórzewska, uczyli słuchaczy krytycznie patrzeć na dzieło, odróżniać je od tandety, szerzyć zamiłowanie do sztuki i ochrony dziedzictwa kulturowego. Na wakacyjnych kursach dla nauczycieli ważne też było przygotowanie techniczne, czyli opanowanie rysunku i malarstwa w takim stopniu, aby byli dobrymi nauczycielami ${ }^{38}$. „W ognisku słuchacze pracują codziennie, zapoznając się z techniką akwareli, tempery, malarstwa olejnego i grafiki, a także zasadami modelowania. Wykłada się im poza tym historię sztuki, uczy się cenić i chronić przed zagładą sztukę ludową, omawia zagadnienia estetyki praktycznej: urządzenia szkolne, dekorację sceniczną, inscenizację. Wieczorem odbywają się odczyty publiczne, poświęcone mistrzom sztuk plastycznych, lub koncerty urządzane staraniem Ogniska Muzycznego"39. Obok zajęć stricte artystycznych i teoretycznych, Władysław Lam uczył metodyki pracy z uczniem. Istotne jest również to, że - podobnie jak Sheybal - Władysław Lam preferował swobodną ekspresję twórczą dziecka zamiast nauki wiernego odtwarzania natury.

Stanisław Sheybal w ROW prowadził pogadanki i ćwiczenia dotyczące sposobów ukazania przestrzeni w obrazie, a także miał odczyty dla plastyków i muzyków o zabytkowej architekturze Krzemieńca ${ }^{4}$. Wspomina, że bliski kontakt ze wspomnianymi powyżej kolorystami miał wyjątkowy wpływ na jego twórczość jako plastyka. Szczególnie cenił sobie wykłady Jerzego Wolffa.

\footnotetext{
34 Ibidem.

35 T. Skórzewska, Wakacyjne Kursy Rysunkowe w Krzemieńcu, op. cit., s. 547.

36 S. Sheybal, Wspomnienia ..., op. cit., s. 133.

37 T. Skórzewska, Wakacyjne Kursy Rysunkowe w Krzemieńcu, op. cit., s. 547.

38 Ibidem.

39 Ibidem.

40 S. Sheybal, Wspomnienia ..., op. cit. s. 262.
} 


\section{Po II wojnie}

Doświadczenia metodyczne wykorzystał Sheybal po II wojnie światowej. Został wówczas powołany przez Ministerstwo Kultury i Sztuki najpierw na stanowisko ministerialnego wizytatora szkół plastycznych, a następnie Naczelnika Wydziału Szkolnictwa Plastycznego ${ }^{4}$.

Jako pracownik Ministerstwa Kultury i Sztuki często współpracował z Lamem przy organizacji form doskonalenia metodyczno-dydaktycznego dla nauczycieli plastyków. Jako malarz, pedagog i pracownik w dziale administracji szkolnictwa artystycznego korzystał też z wiedzy i doświadczeń innego kolegi z ASP krakowskiej - Stanisława Szczepańskiego, późniejszego profesora Wyższej Szkoły Sztuk Plastycznych w Poznaniu i ASP w Warszawie, który wcześniej, od 1937 roku - prowadził wykłady na wakacyjnych kursach w Krzemieńcu. Okres ten Sheybal tak wspominał: „Był to okres intensywnej pracy nad doskonaleniem i utrwalaniem form organizacyjnych i programowych szkół plastycznych, stworzeniem im odpowiednich warunków materialnych oraz szkolenia stałych, możliwie wysoko wykwalifikowanych kadr plastyków pedagogów”ł2.

Warto tutaj wspomnieć o roli, jaką Liceum Krzemienieckie i wakacyjne kursy odegrały dla rozwoju powojennej kadry szkolnictwa plastycznego. Część szkół plastycznych powstawała w Polsce powojennej na bazie Państwowych Ognisk Artystycznych, a te wywodziły się między innymi z tradycji Liceum Krzemienieckiego. We wspomnianych kursach uczestniczyło wielu nauczycieli rysunków, a także późniejsi nauczyciele szkół plastycznych. Po wojnie organizowano wspomniane ogniska plastyczne, a niektóre z nich przekształciły się w szkoły artystyczne (czego przykładem może być Państwowe Liceum Sztuk Plastycznych w Jarosławiu) ${ }^{43}$. Kilka szkół i ognisk plastycznych zachowało ciągłość programową z Atenami Wołyńskimi, przede wszystkim poprzez związki personalne. Uczyli w nich nauczyciele lub wychowankowie Liceum Krzemienieckiego i organizowanych przez tę placówkę form doskonalenia pracy nauczycieli. Wychowanek Aten Wołyńskich i zarazem przyjaciel Stanisława Szeybala, Włodzimierz Tiunin, zasłużony pedagog i artysta, absolwent ASP w Warszawie (początkowo w pracowni Tadeusza Pruszkowskiego, a po wojnie - Jana Cybisa i Wojciecha Jastrzębowskiego), od I949 prowadził zajęcia z przedmiotów plastycznych i pełnił funkcję zastępcy dyrektora w Państwowym Liceum Sztuk Plastycznych im. Wojciecha Gersona w Warszawie. Był też adiunktem na Wydziale Architektury Wnętrz ${ }^{44}$.

Absolwentem szkoły krzemienieckiej był także Stanisław Kopystyński, artysta zasłużony najpierw dla powstania Państwowego Liceum Sztuk Plastycznych w Jarosławiu, a następnie - Wyższej Szkoły Sztuk Plastycznych oraz Państwowego Liceum Sztuk Plastycznych we Wrocławiu (pedagog, jest dziś patronem Zespołu Szkół Plastycznych we Wrocławiu). Absolwentką liceum w Krzemieńcu była Halina Micińska-Kenarowa, żona Antoniego Kenara - w pierwszych latach po wojnie dyrektora zakopiańskiej szkoły plastycznej. Po śmierci męża przejęła kierownictwo w szkole. Przytoczone przykłady pokazują, że nie

\footnotetext{
41 Ibidem, s. 304.

42 Ibidem.

43 Por. B. Lewińska-Gwóźdź, Wystawa artystów - pedagogów szkół artystycznych, absolwentów PLSP w Jarosławiu, Towarzystwo Przyjaciół Sztuk Pięknych w Przemyślu, Przemyśl 1998, s. 5-6.

44 Por. eadem, Kształcenie artystyczne $w$ szkołach plastycznych $w$ Polsce $w$ latach 1944-2017, Wydawnictwo Naukowe UKSW, Warszawa 2018, s 48.
} 
można przecenić roli, jaką odegrały wspomniane kursy dla kształtowania się koncepcji programowych i organizacji szkolnictwa plastycznego w Polsce powojennej45.

Od 1946 roku Sheybal pełnił funkcję naczelnika szkół plastycznych. W latach I954-I957 był kierownikiem Sekcji Plastycznej Centralnego Ośrodka Pedagogicznego Szkolnictwa Artystycznego ${ }^{46}$. COPSA była placówką powołaną w celu doskonalenia metod nauczania, a także, jak to sformułował Wojciech Jankowski, gromadzenia i upowszechniania postępowych i twórczych doświadczeń oraz myśli pedagogicznej szkolnictwa artystycznego ${ }^{47}$.

W okresie powojennym Sheybal pracował także jako nauczyciel w szkolnictwie artystycznym. Był najpierw dyrektorem Ogniska Kultury Plastycznej w Krakowie, a następnie, od I949 roku, nauczycielem Liceum Sztuk Plastycznych w Warszawie. W I949 roku otrzymał też nominację na profesora Wyższej Szkoły Sztuk Plastycznych w Warszawie. W i950 roku, po połączeniu tej szkoły z Akademią Sztuk Pięknych w Warszawie, otrzymał nominację na profesora Wyższej Szkoły Sztuk Plastycznych w Łodzi ${ }^{4}$. W tym czasie pełnił już funkcję wizytatora szkół plastycznych i prowadził wykłady w Studium Pedagogicznym Akademii Sztuk Pięknych w Warszawie. Zatem w dalszym ciągu przyczyniał się do rozwoju kadr plastycznych, a zwłaszcza do kształcenia nauczycieli plastyków.

Warto też wspomnieć o roli, jaką odegrał jako nauczyciel Państwowego Liceum Sztuk Plastycznych w Warszawie w związku z określeniem profilu kształcenia w tej placówce. Szkoły plastyczne po II wojnie podzielono na następujące typy: licea technik plastycznych, których zadaniem było wykształcenie pracowników dla rzemiosła i przemysłu, oraz licea sztuk plastycznych ${ }^{49}$. W latach 6o. zaistniał spór o istotę kształcenia w szkołach plastycznych.

Zwolennicy tendencji kształcenia ogólnoplastycznego ze szczególnym naciskiem na proces wychowania przez sztukę uważali, że szkoły plastyczne powołane są po to, żeby przede wszystkim przygotowywać młodzież do podjęcia studiów na różnych kierunkach w wyższych szkołach artystycznych. Według nich młodzież powinna być przede wszystkim wychowywana do czynnego uczestnictwa w kulturze. Ta świadomość kultury była istotniejsza od przygotowania zawodowego. Dodać tutaj trzeba, że szkoły plastyczne, tak w latach 50. i 60. jak współcześnie, są niewątpliwie polem urzeczywistniania idei wychowania przez sztukę. Termin ten, wprowadzony przez Herberta Reada ${ }^{50}$, w Polsce został podjęty przez klasyków idei: Irenę Wojnar i Bohdana Suchodolskiego ${ }^{51}$. Oczywiście pojęcie to odnosiło się zarówno do kształcenia powszechnego, jak i kształcenia artystycznego w zawodowych szkołach plastycznych. Koncepcja wychowania przez sztukę była koncepcją kształcenia waloryzacyjnego, które w szczególny sposób rozwijało wrażliwość i dyspozycje intelektualne uczniów, a także uczucia i kreatywność. Koncepcja ta może być urzeczywistniona w pełni

\footnotetext{
45 Ibidem.

46 W. Jankowski, Ważniejsze kierunki i dorobek Centralnego Ośrodka Pedagogicznego Szkolnictwa Artystycznego-w 15-lecie działalności, ,Materiały Pomocnicze dla Nauczycieli Szkół i Ognisk Artystycznych”, 1969, z. 120, S. 13.

47 Ibidem, s. 12.

48 S. Sheybal, Wspomnienia..., op. cit., s. 305-306.

49 Obwieszczenie Prezydenta Rzeczpospolitej z dnia 12 września 1947 r.-Organizacja szkót, Dziennik Urzędowy Ministerstwa Kultury i Sztuki z 1948 r., nr 1, poz. 11.

50 H. Read, Education Through Art, Faber and Faber, London 1943.

51 I. Wojnar, Estetyka i wychowanie, PWN, Warszawa 1964; eadem, Perspektywy wychowawcze sztuki, Nasza Księgarnia, Warszawa 1966; Wychowanie przez sztukę, red. I. Wojnar, Państwowe Zakłady Wydawnictw Szkolnych, Warszawa 1965.
} 
jedynie wówczas, kiedy kształtowaniu się osobowości towarzyszy czynne uprawianie sztuki, a takie w największym stopniu jest realizowane w zawodowych szkołach plastycznych. Między innymi właśnie dlatego Irena Wojnar była bardzo zainteresowana powstawaniem i rozwojem tych szkół i osobiście wizytowała wiele placówek ${ }^{52}$. Z drugiej strony występowali przeciwnicy, którzy nie negowali potrzeby wychowania przez sztukę, ale uważali, że szkoły artystyczne przede wszystkim powinny przygotowywać do pracy w rzemiośle artystycznym, zgodnie z nauczaną w szkole specjalnością.

W spór ten zaangażowany był żywo Stanisław Sheybal, który starał się udowodnić, jak bardzo istotne jest kształcenie ogólnoplastyczne i wychowanie przez sztukę. W Liceum Sztuk Plastycznych w Warszawie podjął badania nad wpływem czynnych kontaktów ze sztuką na formowanie osobowości uczniów, o czym tak wspominał: „Po wieloletniej pracy liceum przedłożyło władzom konkretne projekty organizacyjno-programowe, które były formalną i praktyczną resumpcją naszych badań i eksperymentów jako też doświadczeń w dziedzinie wychowania przez sztukę młodzieży plastycznie uzdolnionej, a także najlepszego przygotowania tej młodzieży do życia, do wyższych studiów w różnych dziedzinach sztuki, nauki i techniki oraz do pracy po odbyciu krótkotrwałego kursu w wybranych przez nią zawodach plastycznych [...]. Stwierdzić tylko należy, że w nowym, socjalistycznym ustroju, władze, dążąc do zerwania z zadawnionymi tradycjami pedagogicznymi, pozostawiały nam dużą swobodę działania, a nawet nadały naszemu liceum status szkoły eksperymentalnej. Zbiorową pracą, pod światłym kierunkiem szczerego orędownika naszych idei dyr. Antoniego Mączaka, doszliśmy do bardzo (naszym zdaniem) dobrych rezultatów. Ale w tym czasie dojrzewały już inne, odmienne koncepcje celów, ustrojów i programów średnich szkół plastycznych"s3.

Jak nadmienił Sheybal, badania te przyczyniły się do wyłączenia warszawskiej szkoły z koncepcji uzawodowienia szkół plastycznych i nadania jest statusu szkoły eksperymentalnej. W pozostałych szkołach wprowadzono specjalności zawodowe i przygotowywano uczniów do pracy w konkretnych dyscyplinach, jak na przykład tkactwo, fotografia, wystawiennictwo 54 .

\section{Fotografia jako sposób na wychowanie plastyka według koncepcji Sheybala}

Powzięte jeszcze w czasach pracy w Liceum Krzemienieckim przekonanie, że fotografia jest ważnym elementem wychowania estetycznego, a nawet szerzej - wychowania przez sztukę rozwiną Stanisław Sheybal w artykule metodycznym, opublikowanym w tzw. zeszytach COPSA $^{55}$. Po pierwsze Sheybal uznawał, że fotografia ma walory wychowawcze. Pasjonuje młodzież i stanowi wartościowy sposób spędzania czasu. Ponadto wyrabia cechy, które są niezbędne w zawodzie plastyka, jak: dokładność, staranność i umiejętność organizowania pracy $^{56}$. Znacznie istotniejsze było dla Sehybala jednak to, że fotografia uczy wrażliwej obserwacji świata, a także rozwija indywidualną ekspresję ucznia. W zależności od charakteru

52 Por. B. Lewińska, Ksztatcenie, op. cit., s. 62-63.

53 S. Sheybal, Wspomnienia ..., op. cit., s. 305-306.

${ }_{54}$ Por. B. Lewińska, Ksztatcenie..., op. cit., s. 67.

55 S. Sheybal, Fotografia i film w szkole w: Materiały pomocnicze dla nauczycieli szkót i ognisk artystycznych, z. 94, Centralny Ośrodek Pedagogiczny Szkolnictwa Artystycznego, Warszawa 1966.

56 Ibidem, s. 9. 
fotografii, kształci różne cechy osobowościowe i predyspozycje artystyczne. Na przykład fotografia dokumentalna, która celnie oddawałaby istotę przedmiotu, wymaga wnikliwej analizy zjawisk i osób portretowanych, a następnie wychwycenia cech charakterystycznych, związanych z formą, konstrukcją, materią i funkcją, oraz umiejętności ich uwydatnienia za pomocą środków plastycznych ${ }^{57}$. Z kolei reportaż fotograficzny jest dokumentem nie tylko przedmiotu, zjawiska czy zdarzenia, ale także refleksji własnych i indywidualnej interpretacji autora. Jak zauważył Sheybal, „może reportaż oddziaływać przez zaskoczenie, zaszokowanie niespodziewanym ujęciem tematu, często komizmem, a nawet celnym symbolem. Tym większej bystrości i wnikliwości spojrzenia wymagają zdjęcia reportażowe, pojedyncze czy cykliczne, na tematy zadane lub wybrane przez ucznia. Idzie tu już nie tylko o cechy wewnętrzne, wizualne zjawiska. Uczeń musi zjawisko czy zagadnienie przemyśleć, spostrzec jego aspekty społeczne i celnie a dobitnie wyrazić nie tylko jego charakterystyczne objawy, ale przede wszystkim swój własny stosunek do problematyki danego tematu'58.

Zdaniem Sheybala dobrze poprowadzona fotografia reportażowa nie tylko uczy wnikliwie obserwować i przeżywać zjawiska, ale dostarcza także wiedzy o świecie i przyczynia się do formacji światopoglądowej59. Obok odziaływania wychowawczego i kształtowania intelektualnego, fotografia jest też niezbędnym przedmiotem w procesie kształcenia artystycznego. Sheybal bronił znaczenia fotografii jako dziedziny sztuki, mówiąc: „Olbrzymi rozwój narzędzi, techniki i materiałów fotograficznych, rozszerzający zakres możliwości świadomego kierowania procesami optycznymi i chemicznymi sprawił, że indywidualny, zgodny z wolą i koncepcją twórczą wpływ autora obrazu fotograficznego, decyduje w sposób nie budzący wątpliwości o jego ostatecznym wyglądzie i charakterze. Żaden fotografik nie usłyszy już chyba tak częstego do niedawna okrzyku zachwytu nad jego dziełem «Och, jaki pan ma doskonały aparat», tak jak nikomu nigdy nie przychodziło do głowy wyrazić uznanie wielkiemu pianiście: «Ach, jak pan ma znakomity fortepian»"

Reasumując, zdaniem Sheybala, uprawianie fotografii ma zarówno wartość estetyczną, jak i wychowawczą. Daje pełną możliwość indywidualnej ekspresji, uczy postrzegania piękna w otoczeniu, nawet w zjawiskach, które pozornie nie są piękne. Stwarza też możliwości kształtowania umiejętności interpretacji natury, a nie tylko jej odtwarzania ${ }^{6 \mathrm{r}}$.

Artykuł swój Sheybal pisał w czasie, kiedy tylko w dwóch szkołach plastycznych w Polsce fotografia była nauczana jako odrębny przedmiot szkolny. Artysta niewątpliwie był pionierem we wprowadzaniu tej dyscypliny do programu szkolnego. Nastąpiło to jednak znacznie później, bo dopiero w 1973 roku $^{62}$.

\footnotetext{
57 Ibidem.

58 Ibidem, s. 9-10.

59 Ibidem, s. 10.

60 Ibidem, s. 11.

61 Ibidem, s. 12-13.

${ }^{62}$ Zarządzenie Ministra Kultury i Sztuki z dnia 17 maja 1973 r. w: Liceum Sztuk Plastycznych. Założenia organizacyjno-programowe. Plany nauczania, Ministerstwo Kultury i Sztuki, Zarząd Szkół Artystycznych, Warszawa 1973 , s. $2-4$.
} 


\section{Konkluzje}

Stanisław Sheybal był nie tylko artystą i eksperymentatorem wypowiadającym się przede wszystkim w dziedzinie fotografii, ale także pedagogiem, który dziedzinę tę upowszechniał i przyczynił się do wprowadzenia fotografii jako przedmiotu obowiązkowego w szkołach plastycznych. Jako pedagog miał też znaczący wkład w kształcenie i doskonalenie kadr plastycznych, przygotowanych do podjęcia pracy zarówno w szkołach powszechnych, jak i zawodowych szkołach artystycznych. Był jednym z pionierów idei, aby nauczane w szkołach przed II wojną „rysunki” nie były tylko bezsensownym „trenowaniem” do jak najwierniejszego odtwarzania rzeczywistości, ale stały się też okazją do wychowania przez sztukę $\mathrm{i}$ indywidualnej ekspresji twórczej dzieci.

\section{Stanislaw Sheybal and his role in promoting artistic culture and visual arts education in Poland \\ Abstract}

The figure of Stanisław Sheybal (I89I-I976), painter, distinguished photographer, co-organizer of many cultural and artistic projects, has been the subject of many studies. Usually, the focus was on Sheybal's artistic activities in the field of photography, especially during his work at the Krzemieniecki Secondary School. However, his role as an educationalist and organizer of artistic life, especially after the Second World War, has been insufficiently highlighted.

Before the Second World War, Stanisław Sheybal was a teacher at the Krzemieniec Secondary School. From 1946 he was the head of art schools. Between I954-I957 he was the head of the Art Section of the Educational Centre for Art Education. At the same time, he was the director of the Visual Culture Centre in Krakow and then, from 1949, he was a teacher at the High School of Visual Arts in Warsaw. In 1949 he was also nominated as professor at the Warsaw Academy of Visual Arts, and then he was nominated as professor at the Łódź Academy of Visual Arts. At that time, he was the inspector of visual arts schools and lectured at the Pedagogical College of the Academy of Fine Arts in Warsaw. The artist was the organizer and co-organizer of trainings for music and art teachers as well as teachers of visual arts in art schools. He contributed to the development of visual arts staff. This article shows the figure of the artist primarily as a pedagogue and educationalist of visual art (in public schools) and artistic education (in art schools). The artist's profile has been presented in a broader context. The article uses Sheybal's reflections on teaching, based on the artist's memories and published methodological articles.

Keywords: art education, author of the translation - Stanisław Sokólski, Krzemieniec High School, methodology, Sheybal, teaching photography

\section{BIBLIOGRAFIA}

Bieńkowska A., Juliusz Poniatowski. Biografia polityczna, Wydawnictwo Neriton, Warszawa 2012.

Dzienniki Urzędowe Zarządu Cywilnego Ziem Wołynia i Frontu Podolskiego z I920 r., nr I2, poz. I62.

Jankowski W., Ważniejsze kierunki i dorobek Centralnego Ośrodka Pedagogicznego Szkolnictwa Artystycznego - w I5-lecie działalności, „Materiały Pomocnicze dla Nauczycieli Szkół i Ognisk Artystycznych”, I969, z. I20, s. 5-I3. 
Lewińska B., Kształcenie artystyczne w szkołach plastycznych w Polsce w latach I944-20I7, Wydawnictwo Naukowe UKSW, Warszawa 2018.

Lewińska-Gwóźdź B., Wystawa artystów - pedagogów szkół artystycznych, absolwentów PLSP w Jarosławiu, Towarzystwo Przyjaciół Sztuk Pięknych w Przemyślu, Przemyśl I998.

Obwieszczenie Prezydenta Rzeczypospolitej z dnia I2 września I947 r. - Organizacja szkół, Dziennik Urzędowy Ministerstwa Kultury i Sztuki z I948 r., nr I, poz. II.

Patek A., Sheybal Stanisław Józef, w: Polski Słownik Biograficzny, t. 36, Warszawa-Kraków I995, s. 435-437.

Przybylski R., Krzemieniec. Opowieść o rozsądku zwyciężonych, Wydawnictwo Sic, Warszawa 2003.

Read H., Education Through Art, Faber and Faber, London 1943.

Rolle M., Ateny Wołyńskie. Szkic z dziejów oświaty w Polsce, Ossolineum, Wrocław I923.

Rozporzadzenie Rady Ministrów z dnia Io sierpnia I922 r. w przedmiocie Liceum Krzemienieckiego, Dziennik Urzędowy Rządu Polskiego z I922 r., nr 70, poz. 626.

Rozporzadzenie Rady Ministrów z dnia 3 czerwca 1927 roku o zmianie rozporządzenia Rady Ministrów z dnia Io sierpnia I922 r. w przedmiocie Liceum Krzemienieckiego, Dziennik Ustaw z I927 r., nr 63, poz. 556.

Sheybal S., Ruch fotograficzny w Krzemieńcu, „Życie Krzemienieckie”,I932, nr 8-9, s. 8.

Sheybal S., Fotografia i film w szkole, ,Materiały pomocnicze dla nauczycieli szkół i ognisk artystycznych", 1966, z. 94, s. 7-20.

Sheybal S., Wspomnienia I89I-I970, Wydawnictwo Literackie, Kraków I984.

Sheybal-Rostek A., Szlawski D., Stanistaw Sheybal (I89I-I976). Szkic do portretu, „Zgierskie Zeszyty Regionalne", 20I2, t. 7, s. II3-I28.

Sheybal-Rostek A., Krzemieniec i Liceum Krzemienieckie, „Niepodległość i pamięć”, 2008, nr 27, s. 305-329.

Sheybal-Rostek A., O mnie, http://sheybal.pl/kategoria/o-mnie/ (dostęp: II.II.20I8).

Sheybal-Rostek A., Stanisław Sheybal-krzemieniecki ,mecenas” sztuki, w: Plenery krzemienieckie w latach trzydziestych XX wieku, red. J. Grabski, W. Drohobycka-Grzesiuk, IRSA, Kraków 2013, s. I7I-I83.

Sheybal-Rostek A., Stanisław Sheybal (I89I-1976), krzemieniecki nauczyciel, działacz kulturalny, malarz i fotograf, „Dagerotyp”, 2010, nr 19, s. 63-7I.

Sheybal-Rostek A., W cieniu Góry Bony - rzecz o rodzinie Sheybalów, „Pamiętnik Kijowski”, 2008, t. 9, s. 269-282.

Sheybal-Rostek A., Krzemieniec, http://sheybal.pl/kategoria/krzemieniec/ (dostęp: II.II.20I8). Skłodowski J., Krzemieniec Ateny Wołyńskie - Wolyn Athens, Ad Oculos, Warszawa 2006. Skórzewska T., Wakacyjne Kursy Rysunkowe w Krzemieńcu, „Arkady”, 3/1937, nr I0, s. 547. Stownik terminologiczny sztuk pięknych, Wydawnictwo Naukowe PWN, Warszawa 2003.

Wojnar I., Estetyka i wychowanie, PWN, Warszawa I964.

Wojnar I., Perspektywy wychowawcze sztuki, Nasza Księgarnia, Warszawa 1966.

Wychowanie przez sztuke, red. I. Wojnar, Państwowe Zakłady Wydawnictw Szkolnych, Warszawa 1965.

Zarzadzenie Ministra Kultury i Sztuki z dnia I7 maja 1973 r. w: Liceum Sztuk Plastycznych. Założenia organizacyjno-programowe. Plany nauczania, Ministerstwo Kultury i Sztuki, Zarząd Szkół Artystycznych, Warszawa 1973, s. 2-4. 